\title{
Review on Core Degradation and Material Migration Research in Light- Water Reactors
}

\author{
Jun Wang ${ }^{1 *}$, Chen Wang ${ }^{2}$, Kaiyi Shi ${ }^{1}$ and Guanghui Su ${ }^{3 *}$ \\ ${ }^{1}$ College of Engineering, The University of Wisconsin-Madison, Madison, WI, United States, ${ }^{2}$ Department of Engineering \\ Physics, Tsinghua University, Beijing, China, ${ }^{3}$ Institute of Nuclear Science and Technology, Xi'an Jiaotong University, Xi'an, \\ China
}

Core degradation and material migration research is one of the key areas in severe accident research. A review of core degradation and melting materials immigration research in light-water reactor is important to encourage relevant research. In this paper, both relevant experiments and numerical analyses are reviewed. Due to their high cost, there have only been a few experiments on severe accidents performed. They focus on different aspects of core degradation and material migration, including early stage and

OPEN ACCESS

Edited by: Arunkumar Nayak,

Bhabha Atomic Research

Centre, India

Reviewed by:

Han Zhang,

Karlsruher Institut für

Technologie, Germany

Zeyong Wang,

Rensselaer Polytechnic Institute,

United States

*Correspondence: Jun Wang

jwang564@wisc.edu;

Guanghui Su

ghsu@mail.xjtu.edu.cn

Specialty section:

This article was submitted

to Nuclear Energy,

a section of the journal

Frontiers in Energy Research

Received: 10 October 2017

Accepted: 24 January 2018

Published: 27 February 2018

Citation:

Wang J, Wang C, Shi K and Su G (2018) Review on Core Degradation and Material Migration Research in Light-Water Reactors.

Front. Energy Res. 6:3.

doi: 10.3389/fenrg.2018.00003 late stage accidents in both PWRs and BWRs. All the current experimental data should be fully utilized due to the limited data available. On the other hand, the data available from numerical analyses for severe accidents is very extensive. There are already many systemic severe accident codes developed by different organizations. These codes provide severe accident sequences analysis, severe accident prediction, and are also important in security policy formulation. At the end of this paper, relevant work at Xi'an Jiaotong University is introduced.

Keywords: review, core degradation, melting materials immigration, experiment, numerical analysis

\section{INTRODUCTION}

Since the inception of industrial nuclear power production there have been several severe accidents that have brought drastic damage to local populations and slowed down the advancement of the nuclear industry all over the world. As a consequence, it is very useful to study severe reactor accidents in order to gain a greater understanding of the processes and mechanisms for accidents, assist with relevant nuclear security policy, ensure reactor security, and to protect the public from radiation damage (Bromet, 2012). Core degradation and material migration research is one of the key areas in severe accident research (Hofmann, 1999). It is a multi-phase, multi-component complex physical chemical process, which is hard to accurately predict (Wang et al., 2014a). Due to the huge complexity and uncertainty, severe accident analysis faces a lot of difficulties (Soffer et al., 1995). Thus, a review of core degradation and melting material migration research in light-water reactors can be very helpful to encourage relevant research. A sample of core melting is shown in Figure $\mathbf{1}$ (Zhang et al., 2015a,b).

In this paper, three nuclear severe accidents are overviewed: Fukushima, Chernobyl, and Three Mile Island (Rees, 2009; Morino et al., 2011; Petryna, 2013). These accidents caused a large amount of damage to local populations and remind people to respect the severity of their occurrences (Matzke, 1982; Simmons, 2013). Details of several core degradation and material migration experiments are then described (Hofmann et al., 1997; Schwarz et al., 1999). Some of the experiments focus directly on core degradation and material migration phenomenon (Hagen et al., 1996; Hofmann 


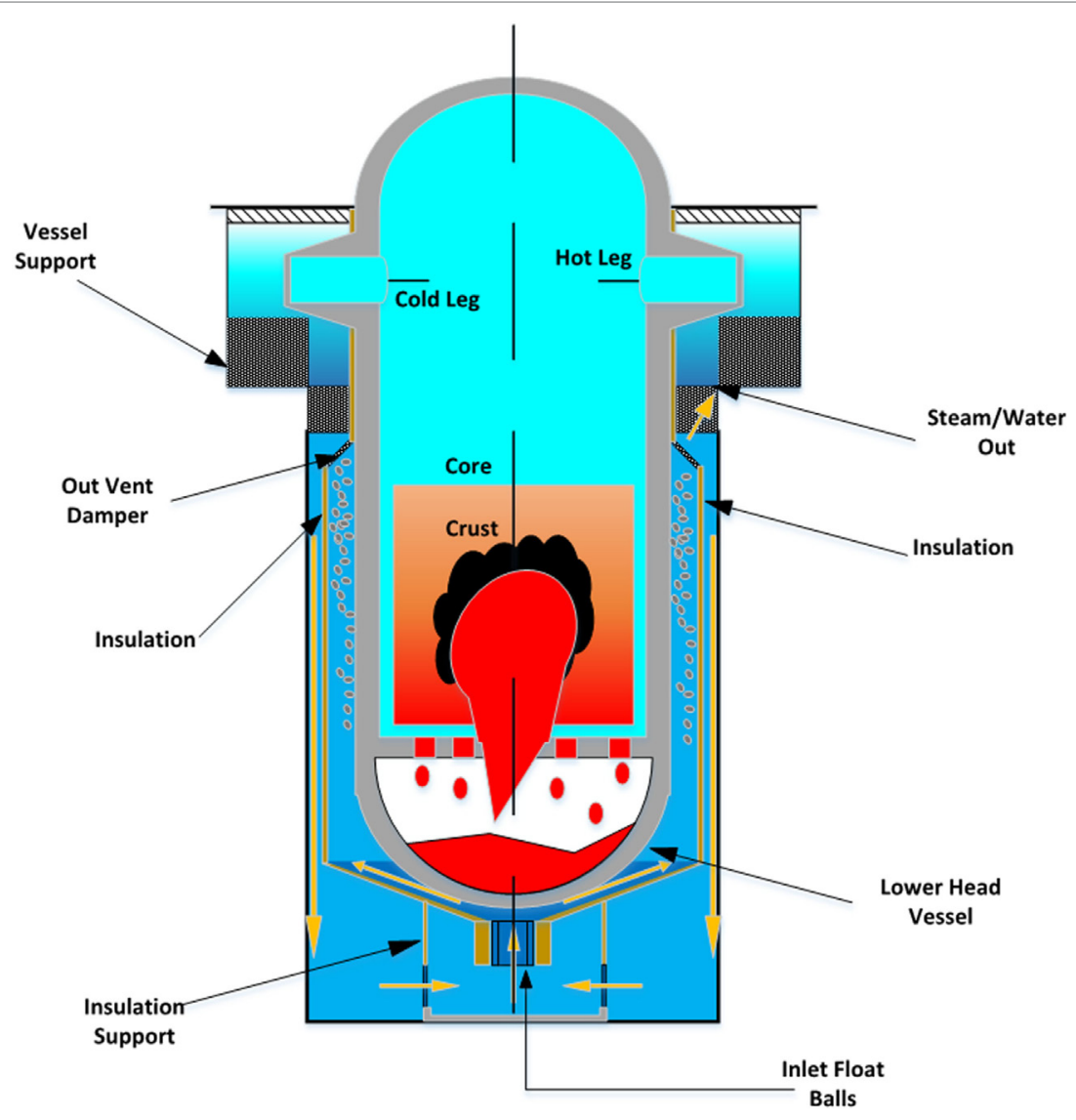

FIGURE 1 | Core melting of AP1000 (Zhang et al., 2015a,b).

et al., 1997; Repetto et al., 2003; Van Dorsselaere et al., 2006), while other experiments deal with separate effects testing of core degradation and material migration phenomenon (Thomsen, 1998; Steinbrück et al., 2010). Next, this paper comes to the numerical investigation and code development of core degradation and material migration (Vierow et al., 2004; Van Dorsselaere et al., 2009). The physical models are reviewed and compared with provide references for relevant research. Finally, in Section "Severe Accident Review at XJTU," the core degradation and material migration research at Xi'an Jiaotong University (XJTU) is overviewed (Sugiyama et al., 2005; Su et al., 2006; Zhang et al., 2011; Chen et al., 2013).

\section{CORE DEGRADATION ACCIDENT REVIEWS AND PRIMARY RESEARCH}

In the history of the nuclear industry, several severe accidents have brought drastic damage to local populations and slowed down the development of nuclear industry all over the world. The accidents at TMI-2, Chernobyl, and Fukushima are the foundation of current severe accident research and provide a valuable insight into probable accident scenarios as well as effectiveness of currently implemented safety systems.

\section{TMI Accident}

On March 28, 1979, a core degradation accident occured in TMI-2 reactor near Harrisburg, Pennsylvania where half of the core melted (Friedman, 2011). This is the first accident that let people realize the speed of a core melt accident and the effectiveness of the implemented safety systems.

The accident began with of the loss of feed water to the steam generators which caused drying out of the steam generator's secondary side for approximately $10-15 \mathrm{~min}$ (Sehgal, 2012). The in-vessel pressure kept increasing, while the turbine stopped running and the reactor shut down. However, the pilot operated relief valve, used to bring down the vessel's pressure, did not close as it was designed. This caused the coolant to continue discharging. The high-pressure emergency-core cooling system (ECCS) was also intentionally closed by the operators, leading to the uncovering of the core for $130 \mathrm{~min}$. The cladding temperature kept rising and oxidizing with steam (Moore et al., 1989). Finally, about $50 \%$ of the core melted down and the blockage formed near the bottom. If the operators had not restarted the cavitating pumps and filled the vessel with water, the core would have probably melted through the vessel and reacted with concrete in the containment, making the TMI-2 accident even more severe (Toth et al., 1986). 


\section{Chernobyl Disaster}

The Chernobyl disaster occurred in one of the four Reaktor Bolshoy Moshchnosty Kanalny (RBMK) reactors in Ukraine, Soviet Union on April 26, 1986 (Howard, 2008). This accident originated from a technology experiment in Chernobyl nuclear power plant which tries to test the available length of a spinning turbine of the electrical power to certain nuclear power plant system (Howieson and Snell, 1987; Sehgal, 2012). Normally, the power would have been reduced to about $30 \%$ to conduct the test, but the operators made a mistake and let the power fell to $1 \%$, which is too low to conduct the test. Meanwhile, the absorption effects from Xenon and liquid water caused the power to continue to decrease. In order to complete the test, operators pulled out almost all the control rods and finally raised the power back to $7 \%$. When the test began, the turbine was disconnected, so the water in the core moved more slowly and began to boil. The reactor power rose sharply due to the positive reactivity feedback of the RBMK reactor. When the operator tried to drive the emergency rods and shut down the reactor, it was too late. The power of the reactor increased up to about 100 times of full-loaded power and greatly destroyed the reactor. The radioactive pollution directly went into atmosphere due to the lack of containment, which caused a negative impact on large areas (Howieson and Snell, 1987; Friedman, 2011).

\section{Fukushima Accident}

On March 11, 2011, the Fukushima accident took place in Japan, which was caused by the unexpected natural disasters of the earthquake and tsunamis. The earthquake caused the loss of the reactors' offsite power and initiated the start of the backup diesel generators as designed. However, the subsequent tsunami disabled the diesel generators, and most of the alternating current power in units 1-4 was lost (Holt et al., 2012; Iida, 2013). Thus, the core cooling capabilities were lost and the water levels in the reactor vessel dropped. Large amounts of hydrogen were generated due to the reaction between steam and the zirconium fuel cladding. This caused a large hydrogen explosion in unit 1 on March 20, causing widespread damage. As reported by TEPCO, all fuel in unit 1 melted to the bottom and most of the fuel even went into the primary containment vessel (PCV) (Friedman, 2011; Holt et al., 2012; Aoki and Rothwell, 2013). Finally, the accident was brought under control as the seawater was injected and offsite power was restored.

\section{EXPERIMENTAL RESEARCH ON CORE DEGRADATION AND MELTING MATERIAL MIGRATION}

Due to the damaging effects of core degradation and material migration, it is very important to perform experimental research in this area. However, these experiments are very expensive and funding limits the number of experiments that can be performed. Therefore, we need to take full advantage of all data collected in these experiments.

CORA core degradation early stage experiments started in the 1980s by Germany's KFK National Lab aiming at International
Standard Problem 31. The CORA experiment focused on PWR, BWR, WER core degradation and quench situation research (Schanz et al., 1992; Hofmann et al., 1997). It includes 19 tests; CORA-13 is represented here as a reference case (Firnhaber et al., 1993a). CORA-13 started November 15, 1990 at KFK. The testing parameters of CORA-13 include experimental boundary conditions, fuel temperature, hydrogen generation rate, postexperiment fuel morphology, and so on. Fuel morphology is recorded by pictures, which are not convenient for quantitative analysis. The primary and boundary conditions are controlled by the experiment input, so there is no need for extra tests for primary and boundary conditions. This operation method allows for better data in each test (Firnhaber et al., 1993b). The excessive high temperature in severe accident conditions, normally higher than $1,500 \mathrm{~K}$, will bring severe damages to the reactor core, such as the interaction between different chemical materials, melting of core materials, relocation, core flow channel blockage, hydrogen generation, etc. In the early stage of severe accidents, the temperature of core is not extremely high. However, to alleviate this situation before too late, it is very important to learn about the core degradation early stage knowledge and make the probabilistic forecasting of severe accident sequence. The CORA experiments are very useful in helping us understand severe accident early stage phenomena and it also promotes the development of other severe accident early stage research (Haste et al., 2015).

The power burst facility-severe fuel damage (PBF-SFD) tests were performed at the Idaho National Engineering Laboratory, during 1982 and 1985. The objectives of these four in-pile experiments were to investigate fuel rod behavior, hydrogen generation, and the behavior of fission products in severe accidents (Knipe et al., 1986; Martinson, 1989; Petti et al., 1989; Hobbins et al., 1991). The primary components of the PBF reactor are a fission drive core, a central flux trap and an independent pressurized water coolant loop (IAEA TECDOC, 2011). The fuel bundle consisted of 32, 0.9-m long, trace-irradiated fuel rods (Knipe et al., 1986). The test process includes power calibration measurements, high-power operation, shutdown, low-power operation, boildown of the coolants, a short period of high temperature, shut down of the power, bundle storage, as well as the examination of the post-test bundle (IAEA TECDOC, 2011). The PBF-SFD in-pile fuel damage experiments were the first tests performed and they have provided most of the analytical results about the degrading of major phenomena.

The PHEBUS experiment aims to solve International Standard Problem 46 which are the core degradation and melting materials migration problems (Gonnier et al., 1992; Schwarz et al., 1999; Clément and Zeyen, 2013; Haste et al., 2015). The research target of PHEBUS is to study the key in-vessel physical phenomenon, including core degradation, fossil fuel transportation, transformation, and relevant physical chemical phenomenon. The PHEBUS-FP test matrix is shown is Table 1. PHEBUS FPT-1 tested a loss of coolant accident (LOCA) in high-density steam condition. This experiment provided scientists a good opportunity to understand the mechanism of core degradation and melting materials migration. To achieve better experimental results, the design of PHEBUS was an exact copy of a light-water reactor. The PHEBUS facility includes a core, steam generator, security vessel, 
TABLE 1 | PHEBUS-FP test matrix (Clément et al., 2003).

\begin{tabular}{|c|c|c|c|c|}
\hline No. & Fuel types & Fuel bundles & Primary circuit & Year \\
\hline FPT-0 & $\begin{array}{l}\text { Fresh fuel } \\
1 \text { Ag-IN-Cd Rod } \\
9 \text { d. Pre-Irrad }\end{array}$ & $\begin{array}{l}\text { Melt progression and FP release in vapor rich } \\
\text { environment }\end{array}$ & $\begin{array}{l}\text { FP chemistry and deposits in } \\
\text { non-condensing steam generator }\end{array}$ & 1993 \\
\hline FPT-1 & $\begin{array}{l}\text { BR3 Fuel } \\
\sim 23 \mathrm{GWd} / \mathrm{tU} \\
1 \mathrm{Ag}-\mathrm{In}-\mathrm{Cd} \text { Rod } \\
\text { Pre-Irrad }\end{array}$ & As FPT-0 with irradiated fuel & As FPT-0 & 1996 \\
\hline FPT-2 & As FPT-1 & As FPT-1 under steam poor conditions & As FPT-1 with effect of boric acid & 2000 \\
\hline FPT-3 & As FPT-1, but with $\mathrm{B}_{4} \mathrm{C}$ instead of $\mathrm{Ag}-\mathrm{In}-\mathrm{Cd}$ & As FPT-2 & As FPT-0 & 2003 \\
\hline FPT-4 & $\begin{array}{l}\text { EdF Fuel } \\
\sim 33 \mathrm{GWd} \text { /tU } \\
\text { No re-irradiation }\end{array}$ & $\begin{array}{l}\text { Low-volatile FP and actinide release from } \\
\mathrm{UO}_{2}-\mathrm{ZrO}_{2} \text { debris bed, up to melting }\end{array}$ & $\begin{array}{l}\text { Integral filters in test device post- } \\
\text { test studies on samples }\end{array}$ & 1999 \\
\hline FPT-5 & Pre-Irrad. As FPT-1 & Fuel degradation and FP release in air conditions & $\begin{array}{l}\text { Deposition and chemistry of FPs } \\
\text { in air conditions }\end{array}$ & 2004-2005 \\
\hline
\end{tabular}

and so on. There are 21 bundles in the core, with 1 control bundle in the center and 20 surrounding fuel rods. The control rod is made up of Ag-In-Cd, while the fuel rods of uranium dioxide. These experiments generated results on fission product behavior, and provided quantifiable information about the progression of the core melts in vessel (Clément et al., 2003).

PNL conducted the NRU-full-length high temperature (FLHT) experiment at the NRU reactor of Atomic Energy of Canada Ltd. by the Coolant Boil-away and Damage Progression program (CBDP) (Lanning et al., 1988; Lombardo et al., 1988). The objective of the CBDP program was to understand the impacts of the boiling-away of coolants and get data from the damage progress of the core at LWR conditions, as well investigate the severe accidents of full-length bundles. The NRU-FLHT hardware for testing includes one NRU reactor and other four parts, namely the steam closure cave, effluent control module, test train assembly, and a data acquisition and control system (IAEA TECDOC, 2011). The FLHT tests made data available on SFD behavior.

To explore the core components of the melt progression behavior of boiling water reactors, the annular core research reactor-damaged fuel (DF) tests were conducted between 1982 and 1989 at Sandia National Laboratory (SNL) (Gauntt et al., 1989; Gasser et al., 1990). The DF test bundles were produced from 9 to 14 half-meter long fresh $\mathrm{UO}_{2}$ fuel rods (IAEA TECDOC, 2011). According to the experiment, some significant data were obtained, including the response of the test bundle components, the oxidation of the $\mathrm{Zr}$ cladding and canister, and the output of $\mathrm{H}_{2}$ from metal oxidation.

In addition to the facilities already mentioned, there are many other core degradation and melting material migration integral facilities, such as CODEX, which aims at investigating the core degradation within the light-water reactors (Hózer et al., 2000; Hózer, 2002; Hozer et al., 2003); LOFT, which aims at investigating the PWR core behavior during LOCA-type sequences (Jensen et al., 1989; Cronenberg, 1992); SANDIA-XR, which aims to determine the conditions under which steady lower core blockages are formed and those where they cannot be formed; SCARABEE, which aims to solve fast reactor security analysis and the behavior of fuel pool caused by a sub-assembly melting at full power; QUENCH, which is to explicitly investigate the effect of re-flooding on bundle degradation (Sepold et al., 2007, 2009; Stuckert et al., 2010, 2011; Stuckert and Steinbrück, 2014); with the tool FARO, researchers are able to conduct large-scale experiments in order to gain better knowledge of things including structure integration, coolant or molten core with less uncertainties considering relocation and melt progression (Hohmann et al., 1987; Magallon and Huhtiniemi, 2001); and KROTOS, aiming at exploring the problem of steam explosion (Magallon et al., 1996; Huhtiniemi et al., 1997; Annunziato et al., 1999; Huhtiniemi and Magallon, 2001).

\section{CODE DEVELOPMENT REVIEW AND RELEVANT APPLICATIONS}

The development of severe accident analysis codes (including core degradation and melting materials migration phenomenon) and numerical simulation are very important parts of severe-core melt research. This work can significantly reduce experiment research costs, cut down research time, and provide a more guided approach to obtaining research results. Several major accident analysis codes are described below along with their capabilities.

The Electric Power Research Institute develops the Modular Accident Analysis Program (MAAP) (Gabor and Henry, 1983; Kenton and Henry, 1983; Plys et al., 1993; Henry et al., 1994). It can perform fast-running full simulations of severe accidents of the light-water and heavy-water reactor. In the aspect of core degradation and melting materials migration calculations, MAAP mixes outside film flow and inner turbulent flow to calculate the mass of melting materials. When there is no contact between rods the outside film flow model is used, otherwise the inner turbulent flow model is used. Regardless of the flow regime, there is crust formation between the outside wall and flow materials. The crust formed will remain in the computational nodes, but other melted material is still allowed to pass by it and run down stream. This is what will remain in the receiving node. Due to the reduced conservative equations and the simplified discretized systems, 
MAAP runs much faster than other codes, but still provides credible results, thus it can be used in probabilistic safety analysis for existing reactors as well as more advanced light-water reactors (Petoukhov et al., 2009; Rychkov and Kawahara, 2015).

Methods for estimation of leakages and consequences of release (MELCOR) is developed at SNLs. It is a computer code modeling light-water severe accident progress integrally (Gauntt et al., 1998; Vierow et al., 2004; Wang et al., 2015b). It is a secondgeneration means to assess plant risks and it is considered to be a substitute of the source term code package (Carbajo, 1993; Ashbaugh et al., 2008). MELCOR can also be used to analyze design-basis accidents for advanced plant application (Tills et al., 2009). To analyze melting materials, MELCOR uses a candling flow model. Candling flow model means melting materials move down and are then relocated in different positions like a candle. Candling models are based on thermal/flow and mechanical theory. In MELCOR's candling model is shown in Figure 2 (Gauntt et al., 1998), the melting materials migrate from top to bottom via gravity, until they are condensed on a model component, or stopped by another blockage. Those condensing materials are called condensed debris and they become part of the model's solid components, which are different from particulate debris.

SCDAP/Reactor Excursion and Leak Analysis Program (RELAP) is designed by Idaho National Laboratories to foresee the behavior of reactor systems in normal or severe accident situations (Allison et al., 1983, 1992; Birchley and Stuckert, 2011). LIQuefaction-flow-SOLidification (LIQSOL) SCDAP/RELAP is used to calculate the clad deformation, the oxidation and heat transfer during liquid clad migration (Mladin et al., 2009). The melting of fuel rods has a great effect on core damage. In some cases, the melting cladding may fall into a low-temperature environment, making the oxidation process slower. In other cases, the blockage in the flow channels will also slow down the oxidation process. Three calculation steps are involved in LIQSOL's model, first, calculating the fuel melting rate around the clad; second, calculating the time it takes melting fuel and clad to leave the oxidation level; third, calculating the geometry of the melting materials migration and oxidation generation.

Xi'an Jiaotong University developed Modular In-vessel Degradation Analysis Code (MIDAC) to simulate the process of

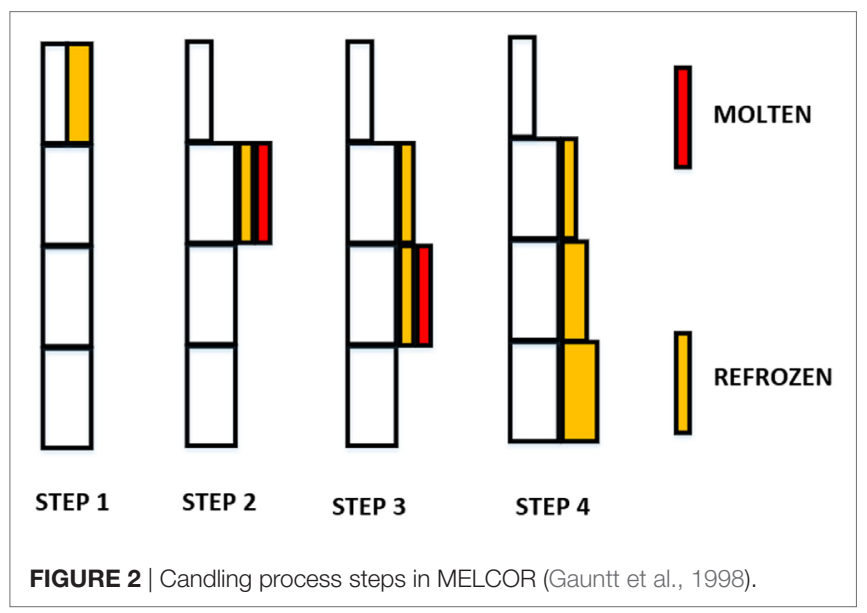

in-vessel severe accidents (Wang et al., 2014b,c; Hu et al., 2015). MIDAC includes five modules for calculations: early-behavior, core degradation, debris bed, molten-materials-in-vessel retention (IVR), and connection modules. Those modules can be used not only to demonstrate the entire severe accident, but also to serve as a link for the conjunction of multiple severe accident codes. Furthermore, the primary and transient thermal-hydraulic system of MIDAC was used to compare with the similar calculations obtained from the module of SCDAP/ RELAP5 and showed good comparison results. MIDAC will play a large role in many Chinese nuclear reactors severe accident analyses.

KESS [Institut Fur Kernenergetik Und Energiesysteme (IKE) modular program system to simulate and analysis core melt accident] is developed by IKE, Germany (Schatz and Hocke, 1995). Its intention of designing this program is to easily simulate the physiochemical processes that occur in the reactor core, during heat up, and the degradation process. It can simulate large amounts of phenomena including: heating up of structures, oxidizing of the cladding, production of hydrogen, expanding and collapsing of mechanical rods, dissolving of $\mathrm{UO}_{2}$, melting and relocating of materials, and releasing and transporting of fission products.

Severe accident analysis code with mechanistic, parallelized simulations oriented toward nuclear fields is an integral analysis code targeting severe accidents included in the IMPACT project (Ujita et al., 1999, 2002; Naitoh et al., 2000). It includes a mechanistic model that indicates many different phenomena, such as the reactor scram and the PCV damage with elaborated mathematical characteristics, and can explain physical behaviors for analytic results.

ICARE/CATHARE is developed at the French Institute for Nuclear Protection and Safety (IPSN), to evaluate severe accidents comprehensively under primary systems (Chatelard et al., 2006; Seiler et al., 2008). The ICARE/CATHARE code is designed to calculate, in a mechanistic way, reactor core damage and primary circuit behavior in PWRs. ICARE/CATHARE features a comprehensive set of models for late degradation allowing the model to follow the materials from their early melting in the core region to their later relocation.

Analysis of thermal-hydraulics of leaks and transients with core degradation is developed by Gasellschaft fur Anlagen und Reaktorsicherheit (GRS) in cooperation with IKE in Germany (Trambauer and Austregesilo, 2003; Austregesilo et al., 2007; Hollands et al., 2007; Repetto et al., 2007). The ATHLET code can be used to predict a spectrum of beyond design-basis accidents for BWRs and PWRs, but without core degradation. The CD part adds functions describing core melting, fission product release, and transport processes in the primary system. The code structure is highly modular so that many models can be included and further developments and changes to the models can be made easier by the users.

Thermal-hydraulic analysis ofloss-of-coolant, emergency-core cooling and severe-core damage designed by Japanese Atomic Energy Research Institute, aims to predict the progression of the core in severe accident conditions of LWRs (Abe et al., 1986; Abe, 1990; Hashimoto and Soda, 1991; Ishikawa et al., 2002). The code was developed for Level 2 PSA and can be used in many assumed 
accidents. It has been applied to serial analyses of experiments, severe accident sequences, and evaluation of designs.

The code ASTEC is a joint research product of GRS (Germany) and IRSN (France) to simulate severe accidents (Van Dorsselaere et al., 2009; Coindreau et al., 2010; Dorsselaere et al., 2012; Chatelard et al., 2014). It is a relatively new and integrated code designed to predict all the behaviors during severe accidents in LWRs, such as any event in the beginning and any event with possible radiation related to a certain fission product. ASTEC has also been widely used in many applications like European pressurized reactor simulating. Table 2 summarizes the codes and their features.

\section{SEVERE ACCIDENT REVIEW AT XJTU}

Xian Jiaotong University is doing a lot of research on core degradation and melting materials migration. The oxidation of the metal core was investigated by Dr. Guanghui Su (Sugiyama et al., 2005). During his research from 2004 to 2006, he proposed an important theory, the "hot spot" during core degradation process (Su et al., 2006). Hot spot is the point which has the highest temperature in the core, which affects the performance of reactor pressure vessel.

Under severe accident conditions, clad oxidation cannot be ignored (Beuzet et al., 2011) since it always weakens the cladding material (Schanz et al., 2004). With the oxidation of cladding material, the accident process can be accelerated, and the integrity of vessel may be threatened by hydrogen generation (Volchek et al., 2004). Dr. Jun Wang made a comparison between CORA and MELCOR steam-oxidation results and showed that the hydrogen generation rate is not predicted as well as expected (Wang et al., 2014a,b). The oxidation model of MELCOR seems to lack mechanical changes during the quenching process which are needed to accurately predict oxidation results. Another model

TABLE 2 | Core degradation simulation codes.

\begin{tabular}{|c|c|c|}
\hline Code name & Supplier & Specialty \\
\hline MAAP & EPRI & $\begin{array}{l}\text { Fast-running full simulations of severe } \\
\text { accidents }\end{array}$ \\
\hline MELCOR & SNL & $\begin{array}{l}\text { Fully integrated, engineering-level } \\
\text { computer code }\end{array}$ \\
\hline SCDAP/RELAP & INL & $\begin{array}{l}\text { Behavior during normal and accident } \\
\text { conditions }\end{array}$ \\
\hline MIDAC & XJTU & Process of in-vessel severe accidents \\
\hline KESS & $\mathrm{IKE}$ & $\begin{array}{l}\text { Most relevant physical and chemical } \\
\text { processes }\end{array}$ \\
\hline SAMPSON & IMPACT & $\begin{array}{l}\text { Mechanistic models that indicate various } \\
\text { phenomena }\end{array}$ \\
\hline ICARE/CATHARE & IPSN & $\begin{array}{l}\text { Mechanistic way to determine core } \\
\text { damage and primary circuit behavior }\end{array}$ \\
\hline ATHLET-CD & GRS and IKE & $\begin{array}{l}\text { Design-basis spectrum and beyond- } \\
\text { design-basis accidents }\end{array}$ \\
\hline THALES & JAERI & $\begin{array}{l}\text { Wide range of postulated accident } \\
\text { scenarios }\end{array}$ \\
\hline ASTEC & IRSN and GRS & $\begin{array}{l}\text { Possible radiological release of fission } \\
\text { products }\end{array}$ \\
\hline
\end{tabular}

developed by Mr. Keyou Mao named Clad solid-phase Oxidation Analysis Code (COAC) has shown better results through verification with a test from the CORA experiments, specifically CORA13. This code COAC is also being used in AP1000 for further clad-oxidation calculations (Mao et al., 2015).

Dr. Ronghua Chen developed a solidified TEXAS-VI code model and applied this code into FARO L14 analysis (Chen et al., 2013). In Chen's work, a model was put forward that studies molten fuel breakup and solidified impacts for the TEXAS-VI code (Chen et al., 2012). The model concentrates on the thermal stress and the solid crust layer effects on fuel particles or fragments. In this model of solidification, the Fourier heat equation was used to study the temporary temperatures and the thickness of fuel particles' crust layers in boundary and initial circumstances. TEXAS-VI was compared with the FARO L14 experiment (Nilsuwankosit et al., 1996) to validate quench and mixed fuel coolants data. Results show that the FARO L14 pressure history, the liquid-water-pool temperature, and the vapor temperature were accordance with the revised model simulation results. FCI explosion energetics were significantly influenced by the mixing performance (Grishchenko et al., 2014). Researchers are still furthering investigating the solidified impacts to study energetics.

It is important to predict the probability, behavior, and the influence of core degradation to calculate the risk and corresponding mitigation (Wang et al., 2014c). However, even until now, all the models of severe accidents are not sufficient and lack precision (Sehgal, 2012). Thus, it is critical to investigate the core degradation mechanisms and to develop solutions for such accidents. Dr. Jun Wang made a core degradation and melting materials migration model that analyzed PHEBUS FPT-1 in MELCOR (Wang et al., 2015a). Through this work, the core degradation parameters, such as pressure, temperature, hydrogen generation, and mass distribution were analyzed. In addition, several parameters are shown by color maps to visualize the core degradation and melting materials migration throughout the accident process.

Dr. Y. P. Zhang is studying a possible solution to critical severecore accidents, named the IVR of core melts (Zhang et al., 2011). Another creative management process named external reactor vessel cooling for IVR analysis was recommended to be used in predicting the reactor cavity flooding and the depressurization process related to severe accidents to determine safety margins of IVR in the AP600. IVRASA proved to be applicable and accurate according to the results produced by UCSB using the FIBS benchmarks. It was also found that the thermal reactions of a couple molten configurations could be predicted.

In addition to the current work of those above, many others are currently pursuing other avenues of severe accident analysis including Dr. Xiaoli Wu's research on loss of pool-cooling accidents in PWRs by applying MAAP5 (Wu et al., 2014). This research involved two cases where the initial water levels differed. Dr. Wei Li also used MAAP5 to analyze the lower head of PWR RPV small break loss of coolant accident scenarios based on high-pressure injection system failures (Li et al., 2014). Dr. Luteng Zhang has performed a MAAP5 estimation of the PWR severe accident setting the pressurizer safety valve stuck-open as the initiating event (Zhang et al., 2015a,b). Results provide a 
clarified explanation of the process and such events as coolant release, ECCS operation, core exposure, etc. Dr. Liang Hu has also investigated the severe accident scenario of $\mathrm{PWR}$ reaction to LOCA along with SBO (Hu et al., 2015).

Xi'an Jiaotong University developed MIDAC for analysis of IVSA to satisfy the domestic requirement for independent scheduling of software (Wang et al., 2014c). Compared with SCDAP/ RELAP5, MIDAC demonstrated a high accuracy in the primary system thermal-hydraulic transient analysis in the CPR1000 station blackout, and the comparison results proved the validity of MIDAC code (Wang et al., 2014c).

In this paper, we reviewed core degradation and melting materials migration research in light-water reactors. The content contains experimental and numerical analyses as well as an overview of current work in the field. Based on analysis and discussion, we can come to the following conclusions:

1. The numbers of severe accident experiments are limited, and their data should be fully utilized for verification of current models and as a guide for future experiments.

2. The development of numerical analyses is quite extensive, and they have the ability to guide the next set of experiments as

\section{REFERENCES}

Abe, K. (1990). THALES, Thermohydraulic LOCA Analysis of BWR and PWR. France: International Atomic Energy Agency (IAEA), Nuclear Energy Agency - OECD/NEA.

Abe, K., Watanabe, N., Ida, M., Nishi, M., and Noguchi, T. (1986). "Overview of development and application of THALES code system for analyzing progression of core meltdown accident of LWR's," in Proceedings of Second International Topical Meeting on Nuclear Power Plant Thermal Hydraulics and Operations, Tokyo, Japan.

Allison, C., Carlson, E., and Smith, R. (1983). SCDAP: a Computer code for Analyzing Light-Water-Reactor Severe Core Damage. Idaho Falls, USA: EG and G Idaho, Inc.

Allison, C., Hohorst, J., Heath, C., and Davis, K. (1992). SCDAP/RELAP 5/ MOD 3 Assessment: Assessment of Early Phase Damage Progression Models. EGG-SSRE-10098.

Annunziato, A., Yerkess, A., and Addabbo, C. (1999). FARO and KROTOS code simulation and analysis at JRC Ispra. Nucl. Eng. Des. 189, 359-378. doi:10.1016/ S0029-5493(98)00268-4

Aoki, M., and Rothwell, G. (2013). A comparative institutional analysis of the Fukushima nuclear disaster: lessons and policy implications. Energy Policy 53, 240-247. doi:10.1016/j.enpol.2012.10.058

Ashbaugh, S. G., Leonard, M. T., Longmire, P., Gauntt, R. O., and Powers, D. A. (2008). Accident Source Terms for Pressurized Water Reactors with High-Burnup Cores Calculated Using MELCOR 1.8.5. Albuquerque, NM: Sandia National Laboratories. SAND2008-6664, 99.

Austregesilo, H., Bals, C., and Trambauer, K. (2007). Post-test calculation and uncertaintyanalysis of theexperiment QUENCH-07 with the system code ATHLET-CD. Nucl. Eng. Des. 237, 1693-1703. doi:10.1016/j.nucengdes.2007.02.019

Beuzet, E., Lamy, J.-S., Bretault, A., and Simoni, E. (2011). Modelling of Zry-4 cladding oxidation by air, under severe accident conditions using the MAAP4 code. Nucl. Eng. Des. 241, 1217-1224. doi:10.1016/j.nucengdes.2010. 04.024

Birchley, J., and Stuckert, J. (2011). "Analysis of QUENCH-ACM experiments using SCDAP/RELAP 5," in Proceedings of ICAPP10, San Diego.

Bromet, E. J. (2012). Mental health consequences of the chernobyl disaster. J. Radiol. Prot. 32, N71. doi:10.1088/0952-4746/32/1/N71 well as being useful for predicating the processes in core melt accidents.

3. The research at XJTU is abundant and can be used for further Chinese research.

\section{AUTHOR CONTRIBUTIONS}

The work is mainly done by JW. CW and KS both contributed to the accomplishment of this work, and GS is the advisor of JW.

\section{ACKNOWLEDGMENTS}

Thanks for Mr. Robert John Armstrong's writing assistance, technical editing, language editing, and proofreading. This work is also supported by Chinese "Program for Changjiang Scholars and Innovative Research Team in University" (no: IRT1280) and Chinese "National Major Projects" (no: 2011 ZX 06004008 004). This work is also supported by Key Supported Discipline of Guizhou Provence (Qian Xuewei He Zi ZDXK[2016]24), 2011 Collaborative Innovation Center of Guizhou Province (Qian Jiao he xietongchuangxin zi [2016]02).

Carbajo, J. J. (1993). Severe Accident Source Term Characteristics for Selected Peach Bottom Sequences Predicted by the MELCOR Code. Washington, DC, USA/TN, USA: Nuclear Regulatory Commission/ Div. of Safety Issue Resolution; Oak Ridge National Lab.

Chatelard, P., Fleurot, J., Marchand, O., and Drai, P. (2006). "Assessment of ICARE/ CATHARE V1 severe accident code," in 14th International Conference on Nuclear Engineering (Miami, FL: American Society of Mechanical Engineers), 145-154.

Chatelard, P., Reinke, N., Arndt, S., Belon, S., Cantrel, L., Carenini, L., et al. (2014). ASTEC V2 severe accident integral code main features, current V2. 0 modelling status, perspectives. Nucl. Eng. Des 272, 119-135. doi:10.1016/j. nucengdes.2013.06.040

Chen, R., Corradini, M., and Su, G. (2012). Simulation of FARO corium coolant interaction experiment with TEXAS-VI. Trans. Am. Nucl. Soc. 106, 1029-1031.

Chen, R., Corradini, M., Su, G., and Qiu, S. (2013). Development of a solidification model for TEXAS-VI code and application to FARO L14 analysis. Nucl. Sci. Eng. 173, 1-14. doi:10.13182/NSE12-10

Clément, B., Hanniet-Girault, N., Repetto, G., Jacquemain, D., Jones, A., Kissane, M., et al. (2003). LWR severe accident simulation: synthesis of the results and interpretation of the first Phebus FP experiment FPT0. Nucl. Eng. Des 226, 5-82. doi:10.1016/S0029-5493(03)00157-2

Clément, B., and Zeyen, R. (2013). The objectives of the Phébus FP experimental programme and main findings. Ann. Nucl. Energy 61, 4-10. doi:10.1016/j. anucene.2013.03.037

Coindreau, O., Duriez, C., and Ederli, S. (2010). Air oxidation of Zircaloy-4 in the $600-1000^{\circ} \mathrm{C}$ temperature range: modeling for ASTEC code application. J. Nucl. Mater 405, 207-215. doi:10.1016/j.jnucmat.2010.07.038

Cronenberg, A. W. (1992). Hydrogen generation behavior in the loft FP-2 and other experiments: comparative assessment for mitigated severe accident conditions. Nucl. Technol. 97, 97-112. doi:10.13182/NT92-A34629

Dorsselaere, V., Auvinen, A., Beraha, D., Chatelard, P., Journeau, C., Kljenak, I., et al. (2012). The European research on severe accidents in generation-II and-III nuclear power plants. Sci. Technol Nucl. Install. 2012:686945. doi:10.1155/2012/686945

Firnhaber, M., Trambauer, K., Hagen, S., Hofmann, P., Schanz, G., and Sepold, L. (1993a). CORA-13 Experiment on Severe Fuel Damage. Koeln (Germany): Gesellschaft fuer Anlagen-und Reaktorsicherheit (GRS) mbH. 
Firnhaber, M., Trambauer, K., Hagen, S., Hofmann, P., Schanz, G., and Sepold, L. (1993b). ISP-31 OECD/NEA/CSNI International Standard Problem n. 31. Cora-13 Experiment on Severe Fuel Damage. Comparison Report. France: Organisation for Economic Co-Operation and Development-Nuclear Energy Agency, Committee on the safety of nuclear installations-OECD/NEA/CSNI, Le Seine Saint-Germain, 12 boulevard des Iles, F-92130 Issy-les-Moulineaux.

Friedman, S. M. (2011). Three Mile Island, Chernobyl, and Fukushima: an analysis of traditional and new media coverage of nuclear accidents and radiation. Bull. Atomic. Scientists 67, 55-65. doi:10.1177/0096340211421587

Gabor, J., and Henry, R. (1983). "The MAAP-BWR severe accident analysis code," in Proceedings of the International Meeting on Light Water Reactor Severe Accident Evaluation, Cambridge, MA.

Gasser, R., Fryer, C., Gauntt, R., Marshall, A., Reil, K., and Stalker, K. (1990). Damaged Fuel Relocation Experiment DF-1: Results and Analyses. US: Nuclear Regulatory Commission. NUREG/CR-4668, SAND86-1030.

Gauntt, R. O., Cole, R., Hodge, S., Rodriguez, S., Sanders, R., Smith, R., et al. (1998). MELCOR Computer Code Manuals. Albuquerque, New Mexico: Division of Systems Technology, Office of Nuclear Regulatory Research, US Nuclear Regulatory Commission.

Gauntt, R. O., Gasser, R., and Ott, L. (1989). The DF-4 Fuel Damage Experiment in ACRR with a BWR Control Blade And Channel Box. Albuquerque, New Mexico: Division of Systems Research, Office of Nuclear Regulatory Research, US Nuclear Regulatory Commission.

Gonnier, C., Repetto, G., and Geoffroy, G. (1992). Phebus Severe Fuel Damage program: Main Experimental Results and Instrumentation Behavior, The Phebus Fission Product Project: Presentation of the Experimental Programme and Test Facility. UK: Elsevier Applied Science.

Grishchenko, D., Basso, S., Kudinov, P., and Bechta, S. (2014). Sensitivity Study of Steam Explosion Characteristics to Uncertain Input Parameters Using TEXAS-V Code, NUTHOS10, Okinawa, Japan, Dec. 14-18, 2014. Japan: Atomic Energy Society of Japan.

Hagen, S., Hofmann, P., Noack, V., Sepold, L., Schanz, G., and Schumacher, G. (1996). Comparison of the Quench Experiments CORA-12, CORA-13, CORA17. Germany: Forschungszentrum Karlsruhe GmbH Technik und Umwelt, Hauptabteilung Ingenieurtechnik.

Hashimoto, K., and Soda, K. (1991). Thermal-Hydraulic Analysis of the Three Mile Island Unit 2 Reactor Accident with THALES Code. Tokyo, Japan: Japan Atomic Energy Research Inst.

Haste, T., Steinbrück, M., Barrachin, M., de Luze, O., Grosse, M., and Stuckert, J. (2015). A comparison of core degradation phenomena in the CORA, QUENCH, Phébus SFD and Phébus FP experiments. Nucl. Eng. Des. 283, 8-20. doi:10.1016/j.nucengdes.2014.06.035

Henry, R., Paik, C., and Plys, M. (1994). MAAP4-Modular Accident Analysis Program for LWR Power Plants. Research Project, User's Manual, Fauske and Associates, Inc, 3131-3102.

Hobbins, R. R., Petti, D. A., Osetek, D. J., and Hagrman, D. L. (1991). Review of experimental results on light water reactor core melt progression. Nucl. Technol. 95, 287-307. doi:10.13182/NT91-A34578

Hofmann, P. (1999). Current knowledge on core degradation phenomena, a review. J. Nucl. Mater. 270, 194-211. doi:10.1016/S0022-3115(98)00899-X

Hofmann, P., Hagen, S. J., Noack, V., Schanz, G., and Sepold, L. K. (1997). Chemicalphysical behavior of light water reactor core components tested under severe reactor accident conditions in the CORA facility. Nucl. Technol. 118, 200-224. doi:10.13182/NT118-200

Hohmann, H., Magallon, D., Schins, H., Zeyen, R., Laval, H., and Benuzzi, A. (1987). Contribution to FBR Accident Analysis: The FARO Programme at JRC, Ispra, Science and Technology of Fast Reactor Safety. Vol. 2, UK: British Nuclear Energy Society.

Hollands, T., Drath, T., and Koch, M. K. (2007). Preliminary Results of QUENCH-10 Calculations Using ATHLET-CD. 13th Int. QUENCH Workshop. Germany: Forschungszentrum Karlsruhe.

Holt, M., Campbell, R. J., and Nikitin, M. B. (2012). Fukushima Nuclear Disaster. Congressional Research Service, 7-5700.

Howard, J. (2008). Chernobyl Nuclear Disaster. Encyclopedia of Quantitative Risk Analysis and Assessment. USA: Wiley Online Library.

Howieson, J., and Snell, V. G. (1987). Chernobyl-a Canadian Technical Perspective. Ontario, Canada: Atomic Energy of Canada Limited CANDU Operations.
Hózer, Z. (2002). Summary of the Core Degradation Experiments CODEX. Budapest, Hungary: KFKI Atomic Energy Research Institute (AEKI).

Hózer, Z., Maróti, L., Nagy, I., and Windberg, P. (2000). CODEX-2 Experiment: Integral VVER-440 Core Degradation Test. Hungarian Academy of Sciences, Central Research Institute for Physics.

Hozer, Z., Windberg, P., Nagy, I., Maroti, L., Matus, L., Horvath, M., et al. (2003). Interaction of failed fuel rods under air ingress conditions. Nucl. Technol. 141, 244-256. doi:10.13182/NT03-A3365

Hu, L., Zhang, Y., Li, L., Su, G., Tian, W., and Qiu, S. (2015). Investigation of severe accident scenario of PWR response to LOCA along with SBO. Prog. Nucl. Energy 83, 159-166. doi:10.1016/j.pnucene.2015.03.014

Huhtiniemi, I., Hohmann, H., and Magallon, D. (1997). FCI experiments in the corium/water system. Nucl. Eng. Des. 177, 339-349. doi:10.1016/ S0029-5493(97)00202-1

Huhtiniemi, I., and Magallon, D. (2001). Insight into steam explosions with corium melts in KROTOS. Nucl. Eng. Des. 204, 391-400. doi:10.1016/ S0029-5493(00)00319-8

IAEA TECDOC. (2011). Mitigation of Hydrogen Hazards in Severe Accidents in Nuclear Power Plants. Tech. Rep., IAEA-TECDOC-1661. Vienna, Austria: IAEA Iida, T. (2013). Fukushima Nuclear Disaster, Vol. 84. Sustainable Energy.

Ishikawa, J., Muramatsu, K., and Sakamoto, T. (2002). Systematic Source Term Analyses for Level 3 PSA of a BWR with Mark-II Type Containment with THALES-2 Code. 10th International Conference on Nuclear Engineering. American Society of Mechanical Engineers, 87-94.

Jensen, S., Akers, D., and Pregger, B. (1989). Postirradiation Examination Data and Analyses for OECD LOFT Fission Product Experiment LP-FP-2. Paris, France: OECD LOFT.

Kenton, M., and Henry, R. (1983). The MAAP-PWR Severe Accident Analysis Code. United States: Light water reactor severe accident evaluation.

Knipe, A. D., Ploger, S. A., and Osetek, D. J. (1986). PBF Severe Fuel Damage Scoping Test. Test Results Report. Idaho Falls, USA: EG and G Idaho, Inc.

Lanning, D., Lombardo, N., Fitzsimmons, D., Hensley, W., and Panisko, F. (1988). Coolant Boilaway and Damage Progression Program Data Report: Full-Length High Temperature Experiment 5, PNL-6540. Richland, WA: Pacific Northwest Laboratories.

Li, W., Wu, X., Zhang, Y., Ma, D., Chen, Y., Tian, W., et al. (2014). Analysis of PWR RPV lower head SBLOCA scenarios with the failure of high-pressure injection system using MAAP5. Prog. Nucl. Energy 77, 48-64. doi:10.1016/j. pnucene.2014.06.009

Lombardo, N., Lanning, D., and Panisko, F. (1988). Coolant Boilaway and Damage Progression Program Data Report: Full-Length High Temperature Experiment 2, PNL-6551. Richland, WA: Pacific Northwest Laboratories.

Magallon, D., and Huhtiniemi, I. (2001). Corium melt quenching tests at low pressure and subcooled water in FARO. Nucl. Eng. Des. 204, 369-376. doi:10.1016/ S0029-5493(00)00318-6

Magallon, D., Huhtiniemi, I., Annunziato, A., Yerkess, A., and Hohmann, Y. (1996). Status of the FARO/KROTOS Melt-Coolant Interactions Tests. Upton, NY, United States: Nuclear Regulatory Commission, Washington, DC (United States). Office of Nuclear Regulatory Research; Brookhaven National Lab.

Mao, K., Wang, J., Li, L., Zhang, Y., Tian, W., Su, G., et al. (2015). Development of cladding oxidation analysis code [COAC] and application for early stage severe accident simulation of AP1000. Prog. Nucl. Energy 85, 352-365. doi:10.1016/j. pnucene.2015.07.010

Martinson, Z. R. (1989). PBF Severe Fuel Damage Test 1-3 Test Results Report. Rockville, MD: Division of Systems Research, Office of Nuclear Regulatory Research, US Nuclear Regulatory Commission.

Matzke, H. (1982). Radiation damage in crystalline insulators, oxides and ceramic nuclear fuels. Radiat. Eff. 64, 3-33. doi:10.1080/00337578208222984

Mladin, M., Dupleac, D., and Prisecaru, I. (2009). Modifications in SCDAP code for early phase degradation in a CANDU fuel channel. Ann. Nucl. Energy 36, 634-640. doi:10.1016/j.anucene.2008.12.026

Moore, R. L., Golden, D. W., and Tolman, E. (1989). Three Mile Island unit 2 degraded core heatup and cooldown analysis. Nucl. Technol. 87, 990-1004. doi:10.13182/NT89-A27691

Morino, Y., Ohara, T., and Nishizawa, M. (2011). Atmospheric behavior, deposition, and budget of radioactive materials from the Fukushima Daiichi nuclear power plant in March 2011. Geophys. Res. Lett. 38. doi:10.1029/2011GL048689 
Naitoh, M., Ikeda, T., Ujita, H., Sato, N., Morii, T., Vierow, K., et al. (2000). Overview of the Simulation System'impact'for Analysis of Nuclear Power Plant Thermal-Hydraulics and Severe Accidents. Barcelona, Spain: SNA 2000. The fourth international conference on supercomputing in nuclear applications.

Nilsuwankosit, S., Moriyama, K., and Corradini, M. (1996). Analysis of FARO-L14 Experiment with TEXAS, ANS Thermal Hydraulics Division Proceedings, 31st National Heat Transfer Conference. Houston, TX: 16-26.

Petoukhov, S., Brown, M., and Mathew, P. (2009). MAAP4-CANDU Application to the PSA level 2 for the Point Lepreau Nuclear Generating Station Refurbishment Project. Alberta, Canada: Annual Canadian Nuclear Society Conference.

Petryna, A. (2013). Life Exposed: Biological Citizens After CHERNOBYL. Princeton, NJ: Princeton University Press.

Petti, D. A., Martinson, Z., Hobbins, R., Allison, C., Carlson, E., Hagrman, D., et al. (1989). Power Burst Facility (PBF) Severe Fuel Damage Test 1-4 Test Results Report. Idaho Falls, ID (USA): Nuclear Regulatory Commission, Washington, DC (USA). Div. of Systems Research; EG and G Idaho, Inc.

Plys, M. G., Paik, C. Y., Henry, R. E., Wu, C., Suh, K. Y., Lee, S. J., et al. (1993). MAAP4 Model and Validation Status, 2nd ASME-JSME International Conference on Nuclear Engineering - 1993.

Rees, J. V. (2009). Hostages of each other: The Transformation of Nuclear Safety Since Three Mile Island. Chicago, IL: University of Chicago Press.

Repetto, G., Clement, B., and Ederli, S. (2003). Analysis of the FPT-0, FPT-1 and FPT-2 Experiments of the PHEBUS FP Program Investigating in-vessel Phenomena During a LWR Accidents.

Repetto, G., De Luze, O., Birchley, J., Drath, T., Hollands, T., Koch, M. K., et al. (2007). Preliminary Analyses of the Phebus FPT3 Experiment Using Severe Accident Codes (ATHLET-CD, ICARE/CATHARE, MELCOR). Germany: The 2nd European Review Meeting on Severe Accident Research (ERMSAR-2007), $1-2$.

Rychkov, V., and Kawahara, K. (2015). ADAPT-MAAP4 Coupling for a Dynamic Event Tree Study. Proceedings of PSA.

Schanz, G., Adroguer, B., and Volchek, A. (2004). Advanced treatment of zircaloy cladding high-temperature oxidation in severe accident code calculations: part I. Experimental database and basic modeling. Nucl. Eng. Des. 232, 75-84. doi:10.1016/j.nucengdes.2004.02.013

Schanz, G., Hagen, S., Hofmann, P., Schumacher, G., and Sepold, L. (1992). Information on the evolution of severe LWR fuel element damage obtained in the CORA program. J. Nucl. Mater. 188, 131-145. doi:10.1016/0022-3115(92) 90462-T

Schatz, A., and Hocke, K.-D. (1995). KESS - a modular program system to simulate and analyze core melt accidents in light water reactors. Nucl. Eng. Des. 157, 269-280. doi:10.1016/0029-5493(95)00997-Q

Schwarz, M., Hache, G., and Von der Hardt, P. (1999). PHEBUS FP: a severe accident research programme for current and advanced light water reactors. Nucl. Eng. Des. 187, 47-69. doi:10.1016/S0029-5493(98)00257-X

Sehgal, B. (2012). Light Water Reactor Safety. A Historical Review. Amsterdam, Netherlands: Elsevier.

Seiler, N., Bertrand, F., Marchand, O., Repetto, G., and Ederli, S. (2008). Investigations on boron carbide oxidation for nuclear reactors safety-general modelling for ICARE/CATHARE code applications. Nucl. Eng. Des. 238, 820-836. doi:10.1016/j.nucengdes.2006.12.008

Sepold, L., Hering, W., Schanz, G., Scholtyssek, W., Steinbrück, M., and Stuckert, J. (2007). Severe fuel damage experiments performed in the QUENCH facility with 21-rod bundles of LWR-type. Nucl. Eng. Des. 237, 2157-2164. doi:10.1016/j. nucengdes.2007.03.020

Sepold, L., Lind, T., Csordás, A. P., Stegmaier, U., Steinbrück, M., and Stuckert, J. (2009). AgInCd control rod failure in the QUENCH-13 bundle test. Ann. Nucl. Energy 36, 1349-1359. doi:10.1016/j.anucene.2009.06.020

Simmons, J. H. W. (2013). Radiation Damage in Graphite: International Series of Monographs in Nuclear Energy. Oxford, UK: Elsevier.

Soffer, L., Burson, S., Ferrell, C., Lee, R., and Ridgely, J. (1995). Accident source terms for light-water nuclear power plants. NUREG- 1465, 6.

Steinbrück, M., Große, M., Sepold, L., and Stuckert, J. (2010). Synopsis and outcome of the QUENCH experimental program. Nucl. Eng. Des. 240, 1714-1727. doi:10.1016/j.nucengdes.2010.03.021
Stuckert, J., Birchley, J., Grosse, M., Jaeckel, B., and Steinbrück, M. (2010). Experimental and calculation results of the integral reflood test QUENCH-14 with M5 ${ }^{\circledR}$ cladding tubes. Ann. Nucl. Energy 37, 1036-1047. doi:10.1016/j. anucene.2010.04.015

Stuckert, J., Birchley, J., Große, M., Jaeckel, B., and Steinbrück, M. (2011). Experimental and calculation results of the integral reflood test QUENCH-15 with ZIRLO $^{\mathrm{TM}}$ cladding tubes in comparison with results of previous QUENCH tests. Nucl. Eng. Des. 241, 3224-3233. doi:10.1016/j.nucengdes.2011. 05.004

Stuckert, J., and Steinbrück, M. (2014). Experimental results of the QUENCH-16 bundle test on air ingress. Prog. Nucl. Energy 71, 134-141. doi:10.1016/j. pnucene.2013.12.001

Su, G. H., Sugiyama, K. I., Aoki, H., and Kimura, I. (2006). Experimental study on coolability of particulate core-metal debris bed with oxidization, (II) fragmentation and enhanced heat transfer in zircaloy debris bed. J. Nucl. Sci. Technol. 43, 537-545. doi:10.1080/18811248.2006.9711132

Sugiyama, K. I., Aoki, H., Su, G., and Kojima, Y. (2005). Experimental study on coolability of particulate core-metal debris bed with oxidization, (I) fragmentation and enhanced heat transfer in zircaloy-50 wt\% Ag debris bed. J. Nucl. Sci. Technol. 42, 1081-1084. doi:10.1080/18811248.2005.9711061

Thomsen, K. L. (1998). Review of the TMI-2 Accident Evaluation and Vessel Investigation Projects. Roskilde, Denmark: Risø National Laboratory.

Tills, J., Notafrancesco, A., and Phillips, J. (2009). Application of the MELCOR Code to Design Basis PWR Large Dry Containment Analysis. Albuquerque, New Mexico: Sandia National Laboratories. SAND2009-2858.

Toth, L. M., Malinauskas, A., Eidam, G., and Burton, H. (1986). The Three Mile Island Accident: Diagnosis and Prognosis. United States: American Chemical Society.

Trambauer, K., and Austregesilo, H. (2003). "Analysis of quenching during the TMI-2 accident with ATHLET-CD," in Proceedings of the Tenth International Topical Meeting on Nuclear Reactor Thermal Hydraulics, Republic of Korea.

Ujita, H., Ikeda, T., and Naitoh, M. (2002). Severe accident analysis code SAMPSON improvement for IMPACT project. JSME Int. J. Ser. B Fluids. Therm. Eng. 45, 607-614. doi:10.1299/jsmeb.45.607

Ujita, H., Satoh, N., Naitoh, M., Hidaka, M., Shirakawa, N., and Yamagishi, M. (1999). Development of severe accident analysis code SAMPSON in IMPACT project. J. Nucl. Sci. Technol. 36, 1076-1088. doi:10.1080/18811248.1999. 9726284

Van Dorsselaere, J., Seropian, C., Chatelard, P., Jacq, F., Fleurot, J., Giordano, P., et al. (2009). The ASTEC integral code for severe accident simulation. Nucl. Technol. 165, 293-307. doi:10.13182/NT09-A4102

Van Dorsselaere, J.-P., Fichot, F., and Seiler, J.-M. (2006). Views on R\&D needs about in-vessel reflooding issues, with a focus on debris coolability. Nucl. Eng. Des. 236, 1976-1990. doi:10.1016/j.nucengdes.2006.03.039

Vierow, K., Liao, Y., Johnson, J., Kenton, M., and Gauntt, R. (2004). Severe accident analysis of a PWR station blackout with the MELCOR, MAAP4 and SCDAP/RELAP5 codes. Nucl. Eng. Des. 234, 129-145. doi:10.1016/j. nucengdes.2004.09.001

Volchek, A., Zvonarev, Y., and Schanz, G. (2004). Advanced treatment of zircaloy cladding high-temperature oxidation in severe accident code calculations: part II. Best-fitted parabolic correlations. Nucl. Eng. Des. 232, 85-96. doi:10.1016/j. nucengdes.2004.02.014

Wang, J., Corradini, M. L., Fu, W., Haskin, T., Tian, W., Zhang, Y., et al. (2014a). Comparison of CORA \& MELCOR core degradation simulation and the MELCOR oxidation model. Nucl. Eng. Des. 276, 191-201. doi:10.1016/j. nucengdes.2014.05.041

Wang, J., Tian, W., Fan, Y., Mao, K., Lu, J., Su, G., et al. (2014b). The development of a zirconium oxidation calculating program module for module in-vessel degraded analysis code MIDAC. Prog. Nucl. Energy 73, 162-171. doi:10.1016/j. pnucene.2014.02.006

Wang, J., Tian, W., Zhang, Y., Chen, L., Li, L., Zhang, L., et al. (2014c). The development of module in-vessel degraded severe accident analysis code MIDAC and the relevant research for CPR1000 during the station blackout scenario. Prog. Nucl. Energy 76, 44-54. doi:10.1016/j.pnucene.2014.05.015

Wang, J., Corradini, M. L., Fu, W., Haskin, T., Zhang, Y., Tian, W., et al. (2015a). Simulation of the PHEBUS FPT-1 experiment using MELCOR and exploration 
of the primary core degradation mechanism. Ann. Nucl. Energy 85, 193-204. doi:10.1016/j.anucene.2015.05.015

Wang, J., Zhang, Y., Mao, K., Huang, Y., Tian, W., Su, G., et al. (2015b). MELCOR simulation of core thermal response during a station blackout initiated severe accident in China pressurized reactor (CPR1000). Prog. Nucl. Energy 81, 6-15. doi:10.1016/j.pnucene.2014.12.008

Wu, X., Li, W., Zhang, Y., Tian, W., Su, G., and Qiu, S. (2014). Analysis of the loss of pool cooling accident in a PWR spent fuel pool with MAAP5. Ann. Nucl. Energy 72, 198-213. doi:10.1016/j.anucene.2014.05.030

Zhang, L., Zhou, Y., Zhang, Y., Tian, W., Qiu, S., and Su, G. (2015a). Natural convection heat transfer in corium pools: a review work of experimental studies. Prog. Nucl. Energy 79, 167-181. doi:10.1016/j.pnucene.2014.11.021

Zhang, Y. P., Niu, S. P., Zhang, L. T., Qiu, S. Z., Su, G. H., and Tian, W. X. (2015b). A review on analysis of LWR severe accident. ASME J. Nucl. Eng. Radiat. Sci. 1, 1-20. doi:10.1115/1.4030364
Zhang, Y. P., Qiu, S., Su, G., and Tian, W. (2011). A simple novel analysis procedure for IVR calculation in core-molten severe accident. Nucl. Eng. Des. 241, 4634-4642. doi:10.1016/j.nucengdes.2011.03.055

Conflict of Interest Statement: The authors declare that the research was conducted in the absence of any commercial or financial relationships that could be construed as a potential conflict of interest.

Copyright $\odot 2018$ Wang, Wang, Shi and Su. This is an open-access article distributed under the terms of the Creative Commons Attribution License (CC BY). The use, distribution or reproduction in other forums is permitted, provided the original author(s) and the copyright owner are credited and that the original publication in this journal is cited, in accordance with accepted academic practice. No use, distribution or reproduction is permitted which does not comply with these terms. 